Article

\title{
GIS-Based Multicriteria Evaluation of Land Suitability for Grasslands Conservation in Chihuahua, Mexico
}

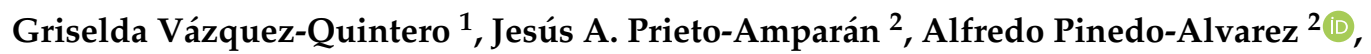 \\ María C. Valles-Aragón ${ }^{1}\left(\mathbb{D}\right.$, Carlos R. Morales-Nieto ${ }^{2}$ and Federico Villarreal-Guerrero ${ }^{2, *(D)}$ \\ 1 Facultad de Ciencias Agrotecnológicas, Universidad Autónoma de Chihuahua, Ave. Pascual Orozco s/n, \\ Campus 1, Chihuahua, Chihuahua 31350, Mexico; gquintero@uach.mx (G.V.-Q.); \\ valles.cecilia@gmail.com (M.C.V.-A.) \\ 2 Facultad de Zootecnia y Ecología, Universidad Autónoma de Chihuahua, Periférico Francisco R. Almada \\ Km 1, Chihuahua, Chihuahua 31453, Mexico; jesus_prieto06@hotmail.com (J.A.P.-A.); \\ apinedo@uach.mx (A.P.-A.); cnieto@uach.mx (C.R.M.-N.) \\ * Correspondence: fvillarreal@uach.mx
}

Received: 5 October 2019; Accepted: 20 December 2019; Published: 25 December 2019

\begin{abstract}
This study developed a GIS-based framework for the zoning of land suitability for grassland conservation (LSGC) in the Central Valleys of Chihuahua, México. For that, a Geographic Information Systems (GIS)-based multicriteria evaluation techniques with weighted overlay (MCE-WO), and a fragmentation analysis were performed. The framework for LSGC consisted in the development of four scenarios: Nonintensive Agriculture, Intensive Agriculture, Urban, and Rural. The LSGC classes defined with the MCE-WO technique were: Very high, High, Moderate, Low, and Very low land suitability. Results showed that the zone with a high suitability covered the largest area in the four scenarios with a surface of $44,264 \mathrm{~km}^{2}$. The zones with low and very low suitability were concentrated mainly in the central region of the study area. At the landscape level, fragmentation of LSGC showed the Nonintensive Agriculture and the Rural scenarios with the highest Number of patches (54,640 and 46,210 , respectively). The fragmentation of LSGC, under the scenarios evaluated, was mainly due to land opening for agriculture and to the influence of rural communities. The integration of GIS with MCE-WO is useful and effective for the evaluation of LSGC. This tool can provide a solid source of information for decision-makers regarding planning of land use to mitigate grasslands degradation.
\end{abstract}

Keywords: conservation zones; MCE; weighted overlay; fragmentation

\section{Introduction}

Grasslands cover about one-third of the world's land area, distributed mainly in semiarid and arid areas [1]. These ecosystems maintain various ecological functions such as water conservation [2], carbon storage [3], and soil stability [4]. Grasslands provide habitat for wildlife, serve as carbon reservoirs, and help mitigate the impacts of global climate change [5]. They also provide environmental services of recreation and appreciation with great views of the landscape [6].

Deforestation, overgrazing, agriculture, displacement of native species, and urbanization accompanied by population growth have induced global desertification and degradation of grasslands, putting at risk the services and functions of these ecosystems [7,8]. Grassland degradation could have a significant impact on the carbon cycle, the regional economy and climate $[9,10]$. In addition, changes in the precipitation regimes due to global environmental change could produce heavy rains with soil saturation in grasslands, which has been proven to have a negative effect on the ecosystem, with a decrease in the reproductive and germination rates in grasslands [11,12]. 
Grasslands in Mexico are distributed over an area of $\approx 100,000 \mathrm{~km}^{2}$ [13]. Specifically, the grasslands of northern Mexico are extensively used for grazing and have also experienced an intensive change in soil due to agricultural activities, resulting in changes in the composition of species in these ecosystems $[14,15]$. Agricultural and livestock activities contribute to more than $75 \%$ of the recent changes in land use, followed by deforestation and urbanization [16].

The establishment of conservation zones for grasslands is of great importance to avoid new disturbances as well as the restoration of degraded grasslands [10]. Many species of both flora and fauna require large areas to maintain their viable populations. The conservation of healthy and functional ecosystems in which biodiversity is maintained in human presence requires the integration of reserve design rules and ecosystem management approaches at the species, ecosystem, and landscape levels [17-19].

Land decision-makers face the problem of selecting the appropriate framework for the establishment of land suitability for grasslands conservation. These zoning decisions are strongly influenced by the type and amount of information available, the land surface area, legislation, and the possibilities of new data collection. The elaboration and establishment of the zoning scheme is possibly the most relevant process in the planning of ecosystem protection zones. Through zoning, specific uses are assigned to the units of the territory to be conserved. The provision of spatial methods and computational technologies to assist land decision-makers in making decisions has had a major influence on land zoning [20-22].

Multicriteria Evaluation (MCE) is a method commonly implemented by decision support systems to compare alternative courses of action based on multiple factors and to identify the solution with the best performance $[23,24]$. MCE has received attention in the context of decision-making based on geographic information systems (GIS) [25-27], which are very useful for solving issues requiring a large set of variables covering extensive territories, which are sometimes inaccessible. For this reason, GIS-based MCE techniques have been used in different studies mainly for decision-making on land use $[28,29]$. Some authors have used MCE techniques to find potential areas for agriculture [22], silvicultural management [30], integrated watershed management [31], settlements development [32], among others. Weighted Overlay (WO) analysis is a component of spatial modeling that uses MCE, placing importance on the criteria in a differentiated manner $[33,34]$. In other words, WO includes different weights in the multicriteria spatial analysis and it is considered different from conventional MCE techniques [35], evaluating the influence of each criterion and assigning values within a defined range of classes [36]. In addition, simulation of scenarios serves to project what will probably happen and may also be used to develop support decision-making processes based on hypothesis of interest [37].

Different criteria at the landscape level, such as roads, agriculture, and urban development, have been shown to have significant negative effects on the spatial configuration of grasslands [38]. The monitoring and quantification of the spatial configuration of grassland ecosystems has been carried out using fragmentation indices, which are of great importance for understanding ecosystem degradation caused by natural and anthropogenic factors [15].

The Central Valleys of the state of Chihuahua is a transition zone between the mountainous area and the Chihuahuan Desert in northern Mexico. Their topography goes from moderate slopes to large plains covered mostly by grasslands, covering $24 \%$ of the State. These grasslands are one of the most suitable ecosystems to sustain domestic herbivorous animals, which, in turn, serve for human consumption. The diversity found in these ecosystems is seriously threatened by changes in land use/land cover, demographic pressure, and the accelerated growth of the surface area occupied by agriculture [39]. Thus, the implementation of a zoning scheme for grassland conservation is of great importance for this region.

The objective was to develop a GIS-based framework for grassland conservation zoning in the Central Valleys of Chihuahua, México. For that, four scenarios of land suitability for grasslands conservation (LSGC) were generated. Scenarios included intensive agriculture, nonintensive agriculture, urban, and rural. Scenario generation was carried out using multicriteria 
evaluation with weighted overlay (MCE-WO) analysis, while the evaluation was performed through a fragmentation analysis. This study was based on GIS and multicriteria evaluation methods and is intended as a tool for local and regional authorities, as well as for land decision-makers. The proposed zoning for LSGC through MCE-WO allows for locating spatial opportunities (i.e., priority areas) for Nature-Based Solutions (NBS) [40-43]. Conservation actions, incorporating nature into decision-making [41], could then be performed in these areas. Focusing on land-use management, through zoning, enables one to optimize NBS through an efficient use of natural resources, and helps in facing future challenges such as the ecosystems' degradation and the global environmental change [44].

\section{Materials and Methods}

\subsection{Study Area}

The Central Valleys have an area of $\approx 59,952.8 \mathrm{~km}^{2}$, distributed in elevations from $1176 \mathrm{~m}$ to $2978 \mathrm{~m}$. The region was delimited based on the map of the terrestrial ecoregion of Mexico [45] and was adjusted to the limits of the state of Chihuahua (Figure 1). The main urban settlements of the area are Chihuahua, Cuauhtemoc, Parral, Casas Grandes, and Nuevo Casas Grandes. The climate of the region is semiarid-temperate, with an average annual temperature range from $12{ }^{\circ} \mathrm{C}$ to $18{ }^{\circ} \mathrm{C}$, and an annual precipitation ranging on average from $300 \mathrm{~mm}$ to $400 \mathrm{~mm}$ [46]. In the grasslands of this region, we can find shrub species and dune vegetation [40]. In some of these grassland ecosystems, mammals such as Bison bison and Cynomys ludovicanus may be found. These species have multiple effects on the ecosystem and both of them are considered key for maintaining the grassland's habitats [47]. Mammal species that can also be found include Puma concolor, which is under pressure, and its populations are in a decreasing status, according to the Red List of threatened species of the International Union for the Conservation of Nature [48].

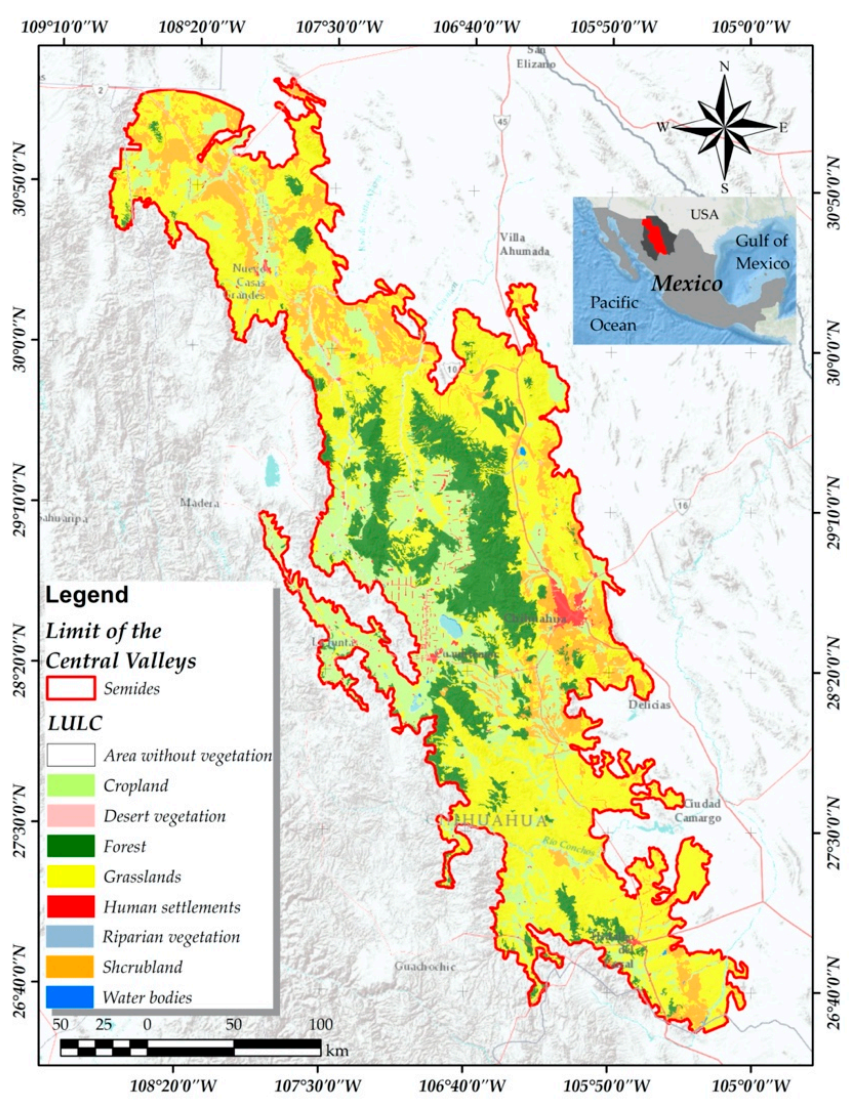

Figure 1. Location of the study area. LULC = Land use/land cover. 


\subsection{Summary of the Framework}

Figure 2 summarizes the methodology used for zoning based on LSGC and for the analysis of the land-suitability configuration in the Central Valleys of Chihuahua, Mexico.

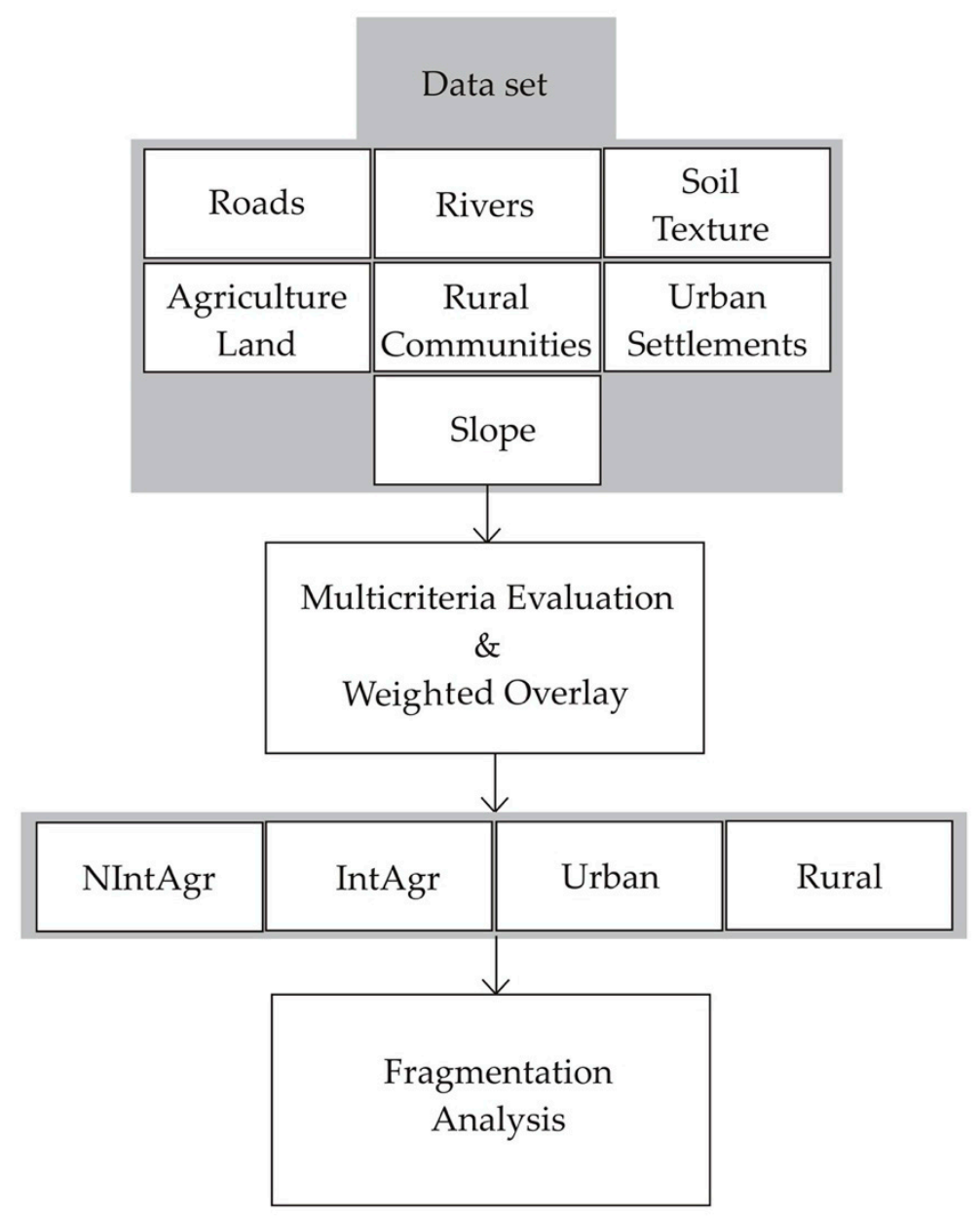

Figure 2. Flowchart summarizing the methodology for the analysis of land suitability for grasslands conservation. NIntAgr $=$ Nonintensive Agriculture, IntAgr $=$ Intensive Agriculture

\subsection{Data Set and Zoning}

Areas of LSGC were defined by using a GIS-based multicriteria evaluation with weighted overlay (MCE-WO) technique. This quantitative method allowed for including qualitative considerations to establish relationships among a set of relevant criteria influencing grassland conservation. Based on expert knowledge [49] and data availability, seven criteria related to LSGC were selected. The criteria, represented in maps and used for the analysis, were: distance to roads, distance to rivers, distance to agricultural areas, distance to urban areas, distance to rural localities (Euclidean distance), slope, and soil texture (Table 1). All these criteria are related, to a greater or lesser extent, to the alteration of areas suitable for grassland conservation.

In addition, areas corresponding to urban settlements and water bodies were excluded for the analysis, since these areas are $100 \%$ not able to be converted into grassland conservation areas. Regarding agriculture lands, they were kept for the analysis since agriculture in the study area usually takes place on the best lands for grasslands conservation and they could be reconverted if policy modifications happened to occur in the future. In the case of the other land use/land cover types, e.g., shrublands and forests, we considered that it was appropriate to include them in the analysis because, 
in the study area, these land use/land covers are associated with grassland vegetation (transition areas), which contribute to maintaining the diversity of the flora and fauna of these ecosystems.

Table 1. Criteria used in the analysis of land suitability for grasslands conservation.

\begin{tabular}{ccc}
\hline Criteria & Unit & Source \\
\hline Distance to agricultural land & $\mathrm{km}$ & INEGI [50] \\
Distance to roads & $\mathrm{km}$ & INEGI [51] \\
Distance to rural communities & $\mathrm{km}$ & INEGI [51] \\
Distance to urban settlements & $\mathrm{km}$ & INEGI [51] \\
Distance to rivers & $\mathrm{km}$ & INEGI [52] \\
Slope & Degree & INEGI [53] \\
Texture & Unitless & INEGI [54] \\
\hline
\end{tabular}

The maps were obtained from various sources and presented different degrees of generalization and scales in vector format. They were then converted to a raster format and homogenized to a cell size of $100 \mathrm{~m}$ by using the ArcMap 10.3@ GIS software (ESRI, Redlands, CA, USA; https: //www.esri.com/en-us/home).

\subsection{Weighted Overlay Analysis}

The MCE-WO was used to reclassify the criteria from Table 1 to the same scale according to their influence on LSGC. Values from 1 to 5 (criteria standardization) were applied to each criterion, as it has been performed on a previous study [55]. According to the degree of suitability for grassland conservation, a value of 1 was assigned to the areas with the lowest suitability, while a value of 5 was assigned to the most suitable areas. The classes manually assigned in this study were: 1 (very low), 2 (low), 3 (moderate), 4 (high), and 5 (very high), as shown in Table 2.

Table 2. Reclassification of the criteria influencing land suitability for grasslands conservation.

\begin{tabular}{|c|c|c|c|c|c|c|c|c|c|c|c|c|c|}
\hline \multicolumn{10}{|c|}{ Distance to } & \multirow{2}{*}{\multicolumn{2}{|c|}{ Slope }} & \multirow{2}{*}{\multicolumn{2}{|c|}{ Texture }} \\
\hline \multicolumn{2}{|c|}{ Agric. Land } & \multicolumn{2}{|c|}{ Roads } & \multicolumn{2}{|c|}{ Rural Communities } & \multicolumn{2}{|c|}{ Urban Settlem. } & \multicolumn{2}{|c|}{ Rivers } & & & & \\
\hline km & $\mathrm{C}$ & km & $\mathrm{C}$ & km & $\mathrm{C}$ & km & $\mathrm{C}$ & km & $\mathrm{C}$ & $\circ$ & $\mathrm{C}$ & Type & $\mathrm{C}$ \\
\hline $0-0.1$ & 1 & $0-0.5$ & 1 & $0-0.5$ & 1 & $0-1$ & 1 & $0-0.5$ & 1 & $0-2$ & 1 & Fine & 1 \\
\hline $0.1-0.5$ & 2 & $0.5-5$ & 2 & $0.5-1$ & 2 & $1-20$ & 2 & $0.5-1$ & 2 & $2-5$ & 2 & Med. & 5 \\
\hline $0.5-1$ & 3 & $5-10$ & 3 & $1-5$ & 3 & $20-30$ & 3 & $1-2$ & 3 & $5-10$ & 3 & Coarse & 3 \\
\hline $1-10$ & 4 & $10-20$ & 4 & $5-10$ & 4 & $30-40$ & 4 & $2-5$ & 4 & $10-20$ & 4 & & \\
\hline $10->$ & 5 & $20->$ & 5 & $10->$ & 5 & $40->$ & 5 & $5->$ & 5 & $20->$ & 5 & & \\
\hline
\end{tabular}

Agric. = Agriculture; Settlem $=$ settlements; $\mathrm{C}=$ Class; Med. $=$ Medium.

Maps of distances to agricultural lands, roads, rural communities, urban settlements, and rivers were classified into the five aforementioned classes. These are relevant because the distance to anthropogenic activities, or the distance to incentives for anthropogenic activities (i.e., rivers), affects the grassland's suitability for conservation. As distances are small, susceptibility decreases.

There is no consensus in the literature about the proximities or the criteria used in this study. Hence, we proposed the distance ranges stated in Table 2. The range used for each class was defined by expert knowledge and by literature review, as it has been performed previously [56]. In addition, the first class of each criterion was defined with the shortest range because we assumed that the nearest distance has the strongest influence.

The distances to agricultural lands were classified into 5 classes, the lowest value being assigned to the lowest distances $(0-0.1 \mathrm{~km})$, because we assumed that the shortest distances have the strongest influences on changing the configuration of the landscape. The distances to roads and rural communities were also classified into 5 classes by assigning the lowest value to the shortest distances $(0-0.5 \mathrm{~km})$. 
Likewise, urban areas were classified into 5 classes, assigning the lowest value to the nearest distance $(0-1.0 \mathrm{~km})$. The proximity to rivers can attract anthropogenic activities and, consequently, increase soil erosion. The map of distance to rivers was classified into 5 classes, assigning the lowest suitability to the shortest distances. Regarding slope, low values $\left(0-2^{\circ}\right)$ make the land more suitable for the establishment of anthropogenic activities, such as cropping or grazing. These criteria specify the horizontal distance at which the anthropogenic activity could cause an alteration.

The soil textures were classified into 3 classes. Fine textures are associated with small pore sizes, which do not favor infiltration, and the soil tends to become saline. Conversely, when soil textures are coarse, pores are large and the soil gets dry quickly, preventing appropriate root development of grasses. Therefore, the highest suitability value was assigned to the medium texture, while the coarse and fine textures got suitability values of 3 and 5, respectively.

Based on expert knowledge and on the literature, the technique would result in a spatially explicit index to evaluate the suitability of areas for grassland conservation.

\subsection{Scenarios}

After reclassifying the criteria, four scenarios were generated. A scenario was produced by ranking, with the highest weight being a criterion of interest to reflect its importance for LSGC. The result was then represented in a map. Four weighting scenarios were considered for this study (Table 3). The first scenario corresponded to Nonintensive agriculture, where it is assumed that agriculture land, rural communities, and urban settlements (criteria) produce the same pressure on grassland conservation. It was represented by assigning a weight of 20 to each one of these criteria. The second scenario considered intensive agriculture as the criterion emitting the highest pressure. Under this case, agriculture is the main driver for the modification of the landscape and, consequently, the alteration of grasslands. That was represented by giving a weight of 40 to this criterion. The Urban criterion, with a weight of 40, was considered as the main alteration driver for the third scenario. Similarly for the fourth scenario, rural communities, with a weight of 40 , were considered as the main landscape modifier. Under this scenario, dispersed localities of the rural type have the greatest pressure on the territory.

Table 3. Proposed scenarios and weighting (\%) of the criteria based on their influence on the land suitability for grasslands conservation.

\begin{tabular}{ccccc}
\hline Scenario & Nonintensive Agriculture & Intensive Agriculture & Urban & Rural \\
Criteria & 20 & 40 & 15 & 20 \\
Agriculture land & 10 & 10 & 10 & 10 \\
Roads & 20 & 20 & 10 & 40 \\
Rural communities & 20 & 5 & 40 & 5 \\
Urban settlements & 10 & 10 & 10 & 10 \\
Slope & 10 & 5 & 5 & 10 \\
Rivers & 10 & 10 & 10 & 5 \\
Texture & 100 & 100 & 100 & 100 \\
\hline Total & & & &
\end{tabular}

The weights assigned to the criteria in each scenario represent the strength or influence of each criterion within the scenario. The values of each pixel from each criterion are multiplied by its corresponding weight (Figure 3). This is repeated for each criterion, the resulting values are added and then rounded to the nearest integer before they are assigned to each pixel to obtain a final map for one scenario. Within each scenario, the lower the cumulative value for each pixel, the lower the LSGC. Conversely, the higher the cumulative value for each pixel, the higher the suitability. 

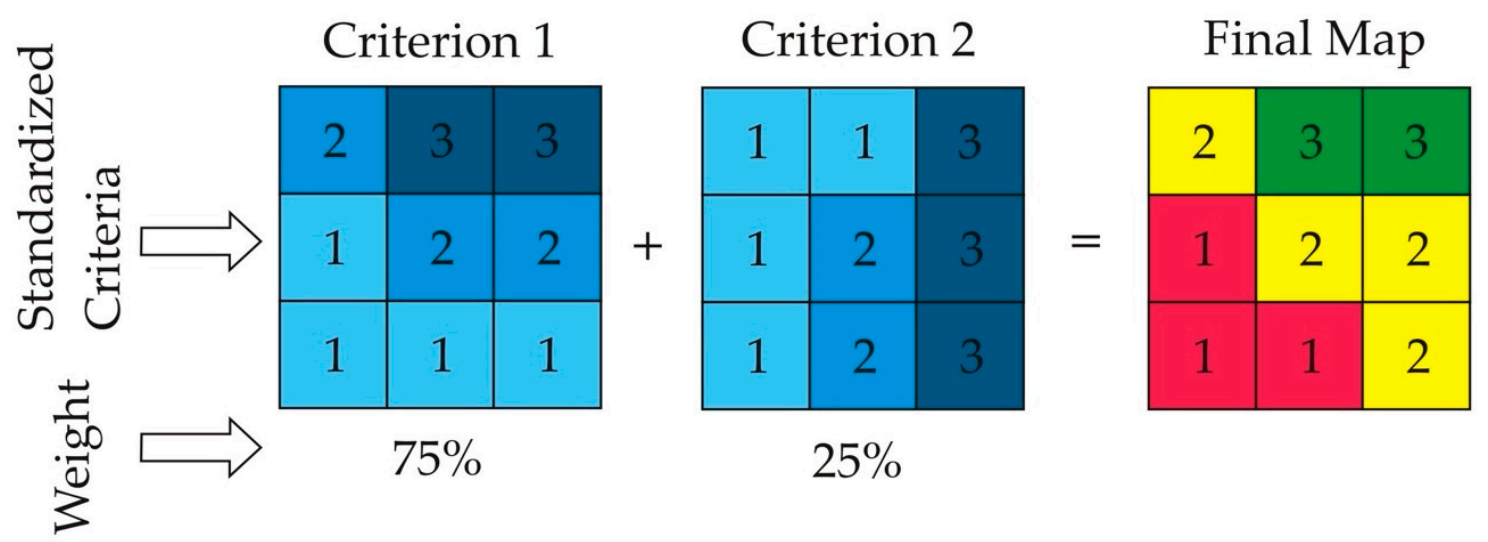

Figure 3. A schematic example of the final map generation of a scenario with the MCE-WO technique. MCE-WO: multicriteria evaluation techniques with weighted overlay.

Finally, the categories assigned to the cumulative values were: Very high, High, Moderate, Low and Very low, as can be seen in Table 4. The LSGC considered as Very high includes the greatest distance to roads, agricultural areas, rural communities, urban settlements, rivers, moderate slopes, and medium soil textures. Meanwhile, areas with Very low LSGC are those showing proximity to agriculture lands, roads, rural communities, urban settlements, rivers, low slopes, and fine soil textures.

Table 4. Definition of land-suitability classes for grasslands conservation.

\begin{tabular}{ccl}
\hline Land-Suitability Class & Value & \multicolumn{1}{c}{ Description } \\
\hline Very high & 5 & $\begin{array}{l}\text { Optimal lands for the development of areas for grasslands } \\
\text { conservation activities together with other land cover types. } \\
\text { This allows for maintaining diversity. }\end{array}$ \\
\hline High & 4 & $\begin{array}{l}\text { Lands with good characteristics for grasslands conservation } \\
\text { together with other land cover types, which allows for maintaining } \\
\text { diversity. However, some patches corresponding to human } \\
\text { activities could be found close by. }\end{array}$ \\
\hline Moderate & $\begin{array}{l}\text { Lands, which are moderately appropriate for the implementation of } \\
\text { grasslands conservation activities because of the close presence of } \\
\text { anthropogenic activities. }\end{array}$ \\
\hline Low & 2 & $\begin{array}{l}\text { Lands that are not good for grasslands conservation activities, } \\
\text { either because anthropogenic activities take place nearby or } \\
\text { because natural conditions do not favor conservation of grasslands. }\end{array}$ \\
\hline Very low & $\begin{array}{l}\text { Lands with very bad conditions for the development of grasslands } \\
\text { conservation activities. There exists a direct influence from } \\
\text { anthropogenic activities. }\end{array}$ \\
\hline
\end{tabular}

The reclassification of the input maps and the MCE-WO was carried out using the Reclassify and Weighted Overlay tool, respectively. The software used for that purpose was ArcMap 10.3C) software (ESRI, Redlands, CA, USA; https://www.esri.com/en-us/home).

\subsection{Scenarios Comparison through Landscape Indexes}

Fragmentation analysis was used to understand the land-suitability configuration for grasslands conservation within each scenario [57]. The metrics of the fragmentation analysis show numerical information about the land-suitability composition, configuration, and dimension. They also allow comparisons of different times and even help recreate future scenarios [58,59]. Consequently, landscape metrics have been widely used to study large natural areas, the evolution of grasslands, urban expansion, among others [15]. 
Landscape metrics can be applied at three different scales: landscape, class, and patch [57]. Landscape and class metrics were only used in this study. Nine metrics were calculated for the proposed scenarios by using FRAGSTATS v4.2@ software (UMASS, Amherst, MA, USA; https: //www.umass.edu/landeco/research/fragstats/fragstats.html), calculating land-suitability heterogeneity, fragmentation, and connectivity [60] (Table 5). The selection of landscape metrics was made based on previous studies $[15,61]$.

Table 5. Metrics employed in the analysis of land-suitability configuration for grasslands conservation.

\begin{tabular}{lccc}
\hline \multicolumn{1}{c}{ Index } & Acronym & Level of Analysis & Type \\
\hline Number of Patches & NumP & L/C & Fragmentation \\
Patch Density & PD & L/C & Fragmentation \\
Edge Density & ED & L/C & Fragmentation \\
Mean Patch Size & MPS & L/C & Fragmentation \\
Perimeter-Area Fractal Dimension & PAFRAC & $\mathrm{L}$ & Fragmentation \\
Shannon's Diversity Index & SHDI & $\mathrm{L}$ & Heterogeneity \\
Percentage of Landscape & PLAND & $\mathrm{C}$ & Fragmentation \\
Euclidean Nearest-Neighbor Distance & ENN_MN & $\mathrm{C}$ & Connectivity \\
Patch Cohesion Index & COHESION & $\mathrm{C}$ & Connectivity \\
\hline
\end{tabular}

$\mathrm{L}=$ Landscape $\mathrm{C}=$ Class.

\section{Results}

\subsection{Spatial Distribution of LSGC}

The application of the MCE-WO technique made it possible to identify areas of LSGC based on seven criteria selected and applied to the Central Valleys of the state of Chihuahua. That allowed for zoning and spatially representing the land suitability based on five classes within four scenarios. The surface areas of the land-suitability categories are shown in Table 6 . The very high suitability zone resulted with a surface that went from $1050 \mathrm{~km}^{2}$ (rural) up to $5763 \mathrm{~km}^{2}$. The high-suitability zone was the one covering most of the surface for the four scenarios with areas ranging from 34,619 $\mathrm{km}^{2}$ (intensive agriculture) to $44,264 \mathrm{~km}^{2}$ (urban). The moderate suitability zone has an area ranging from $6653 \mathrm{~km}^{2}$ (urban) to 19,559 $\mathrm{km}^{2}$ (nonintensive agriculture). The low and very low zones showed surfaces ranging from $60 \mathrm{~km}^{2}$ (nonintensive agriculture) to $5565 \mathrm{~km}^{2}$.

Table 6. Surface area occupied by five land-suitability classes for grasslands conservation in the Central Valleys of Chihuahua in four different scenarios.

\begin{tabular}{|c|c|c|c|c|c|c|c|c|}
\hline \multirow{2}{*}{ LSC } & \multicolumn{2}{|c|}{ Nonintensive Agriculture } & \multicolumn{2}{|c|}{ Intensive Agriculture } & \multicolumn{2}{|l|}{ Urban } & \multicolumn{2}{|l|}{ Rural } \\
\hline & Surface $\left(\mathrm{km}^{2}\right)$ & $\%$ & Surface $\left(\mathrm{km}^{2}\right)$ & $\%$ & Surface $\left(\mathrm{km}^{2}\right)$ & $\%$ & Surface $\left(\mathrm{km}^{2}\right)$ & $\%$ \\
\hline Very high & 1178 & 1.96 & 1141 & 1.90 & 5763 & 9.61 & 1050 & 1.75 \\
\hline High & 36,072 & 60.17 & 34,619 & 57.74 & 44,264 & 73.83 & 38,752 & 64.64 \\
\hline Moderate & 19,559 & 32.62 & 18,426 & 30.73 & 6653 & 11.10 & 17,456 & 29.12 \\
\hline Low & 3084 & 5.14 & 5565 & 9.28 & 3085 & 5.15 & 2533 & 4.23 \\
\hline Very low & 60 & 0.10 & 202 & 0.34 & 188 & 0.31 & 161 & 0.27 \\
\hline Total & 59,953 & 100 & 59,953 & 100 & 59,953 & 100 & 59,953 & 100 \\
\hline
\end{tabular}

In the nonintensive agriculture scenario (Figure 4), the high land-suitability area predominated $(60 \%)$, followed by the moderate land-suitability zone (32.62\%). In the intensive agriculture scenario, high and moderate land-suitability areas also dominated with $57.74 \%$ and $30.73 \%$, respectively. The same behavior was registered for the urban and rural scenarios. 


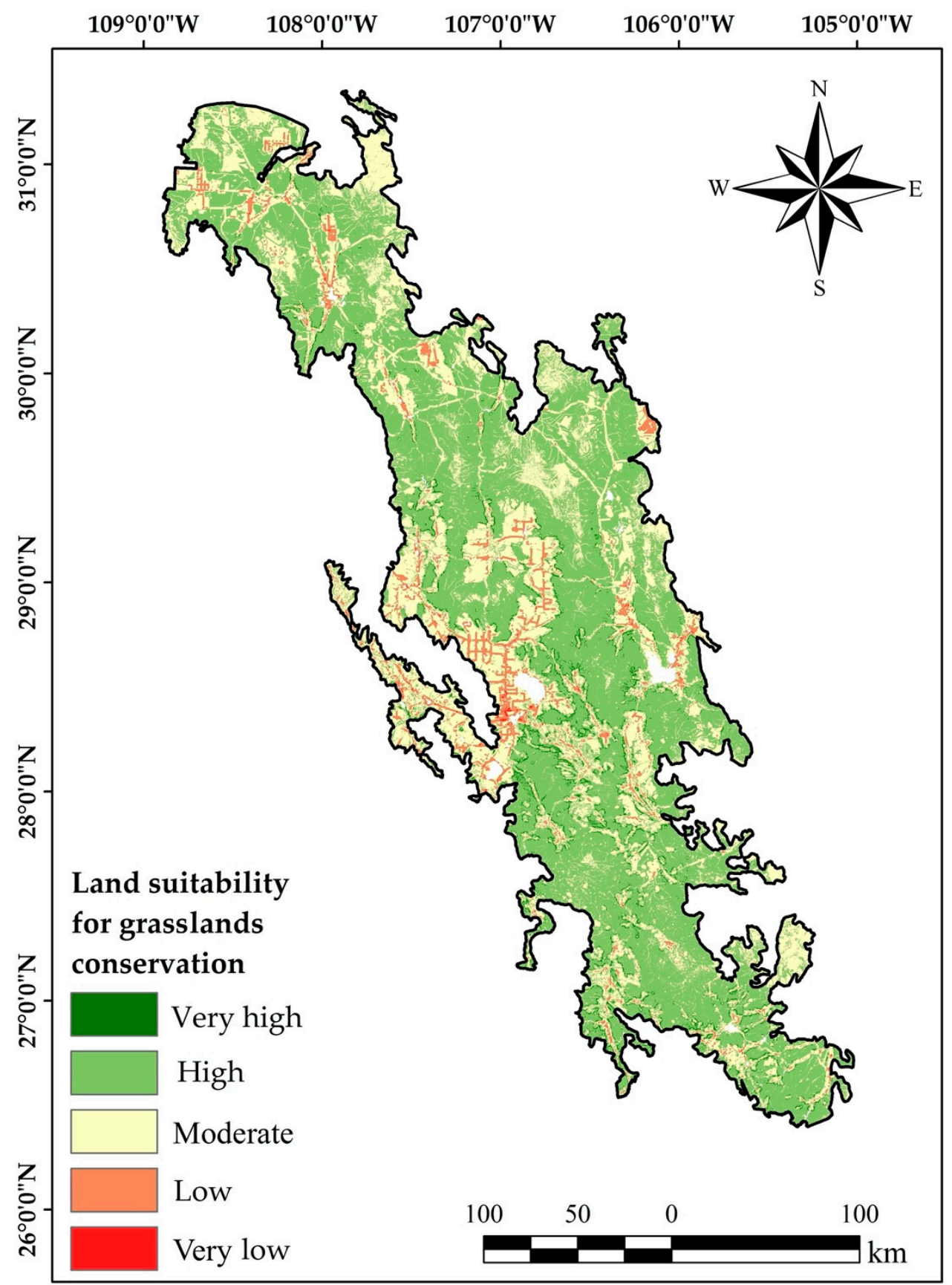

Figure 4. Spatial distribution of land suitability for grasslands conservation in the Central Valleys of the state of Chihuahua. Nonintensive Agriculture scenario.

Regarding land-suitability distribution, in the nonintensive agriculture scenario (Figure 4), very high suitability areas for grasslands conservation are small and distributed throughout the study area. Instead, the high suitability areas are large and distributed throughout the central valleys. The low and very low zones are distributed mainly in the central part of the study area, with some isolated surfaces along the central valleys.

For the intensive agriculture scenario (Figure 5), very high suitability areas resulted with a reduced distribution, mainly located at the edge of the high and moderate suitability areas. The high suitability zones had a distribution similar to the previous scenario. The low and very low suitability zones showed a reduction in their surface areas, which became concentrated mainly to the central and northern central valleys. 


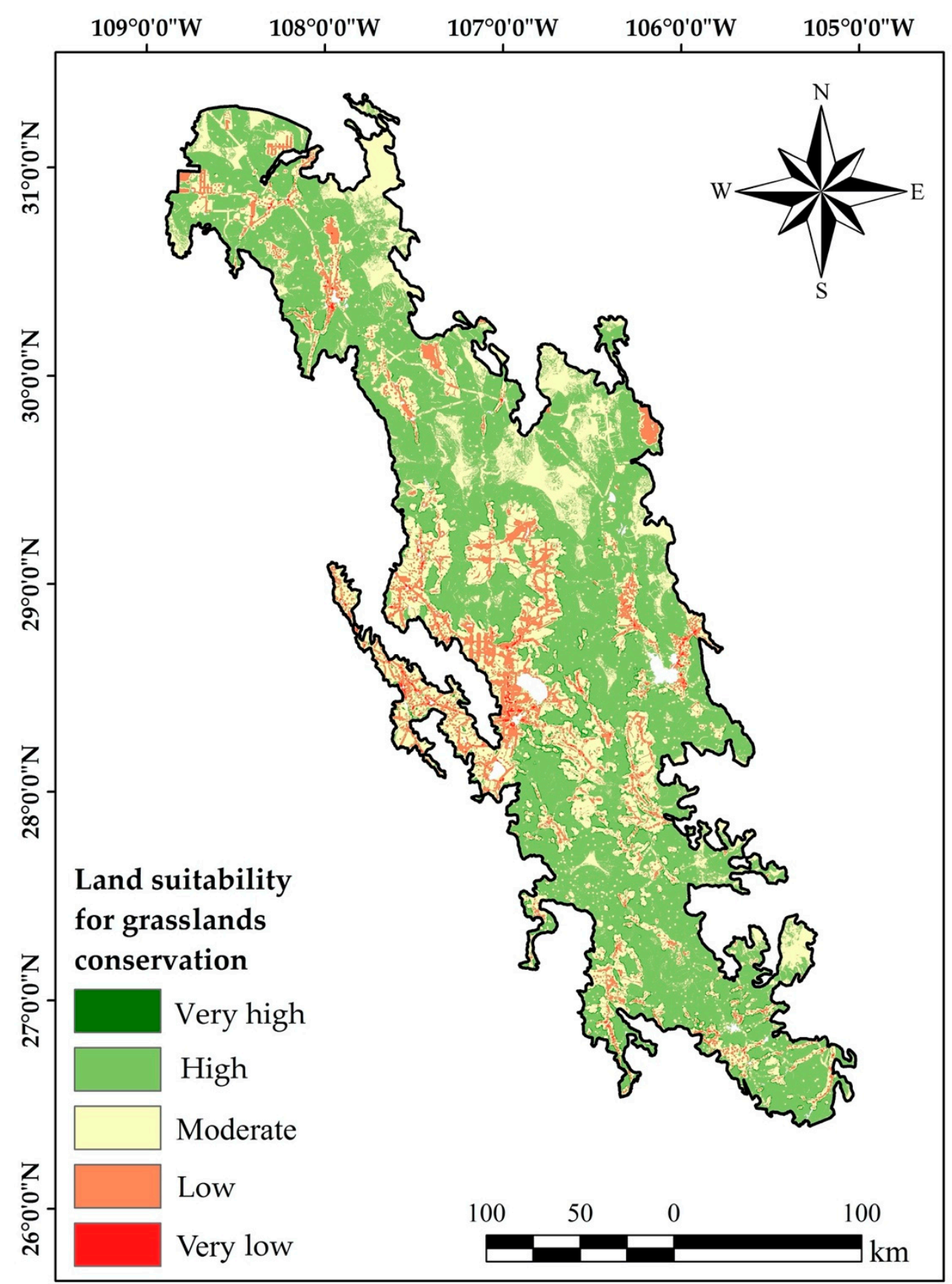

Figure 5. Spatial distribution of land suitability for grasslands conservation in the Central Valleys of the state of Chihuahua. Intensive Agriculture scenario.

For the urban scenario (Figure 6), the areas with very high LSGC have a larger surface area compared to the previous scenarios. The high suitability areas are continuously distributed throughout the central valleys, without presenting isolations. The low and very low areas show a reduction in their surface areas, concentrated in urban areas, as the main driver of change for this scenario. 


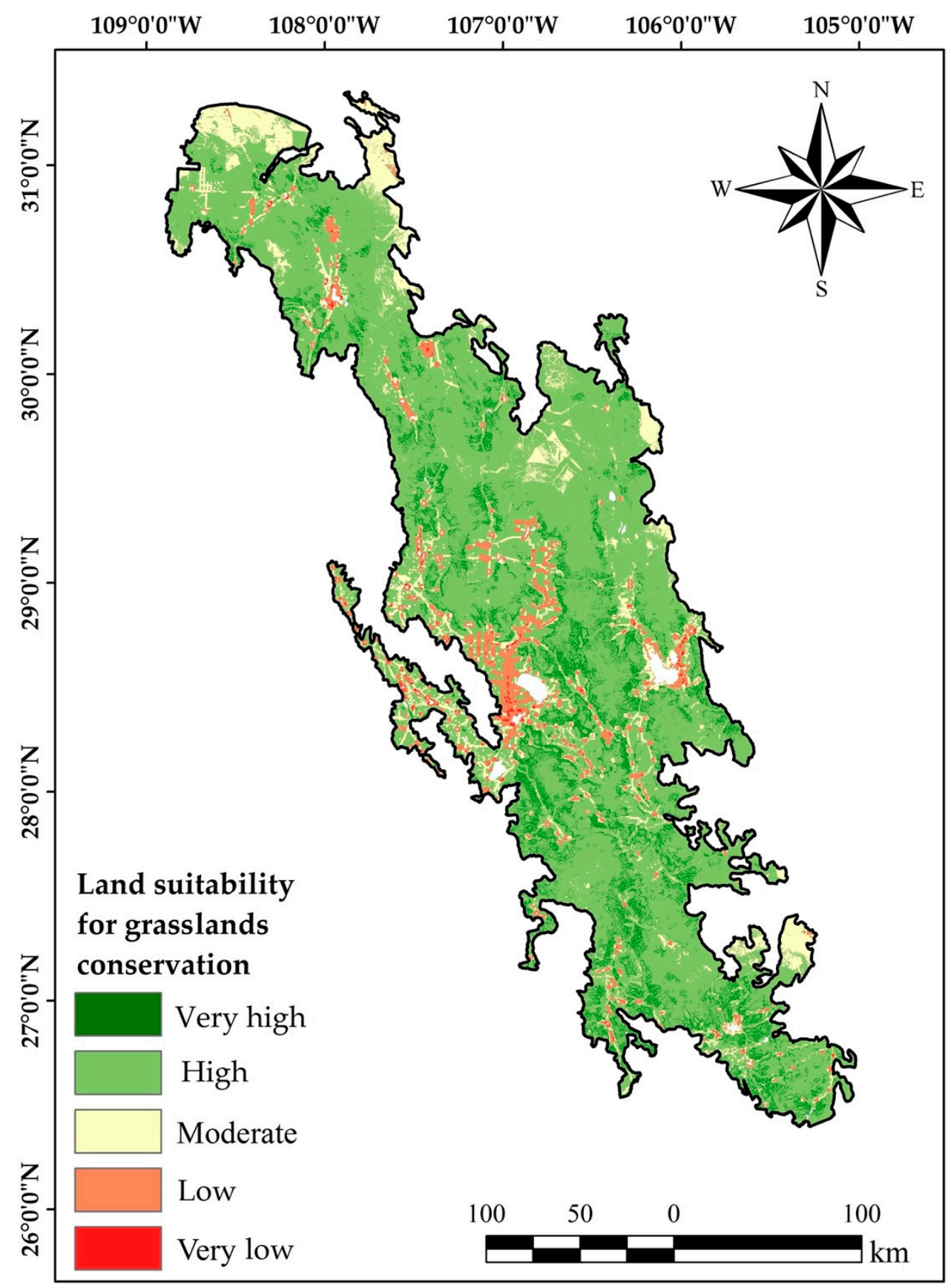

Figure 6. Spatial distribution of land suitability for grasslands conservation in the Central Valleys of the state of Chihuahua. Urban scenario.

For the rural scenario (Figure 7), areas with very high LSGC were small with a dispersed distribution. The high-suitability areas are widely distributed through the central valleys. The low and very low suitability areas show a reduction in surface area compared to the previous scenario, concentrated in the central part of the central valleys. For this scenario, the moderate suitability zones increased their area, but with a dispersed distribution of the rural communities. 


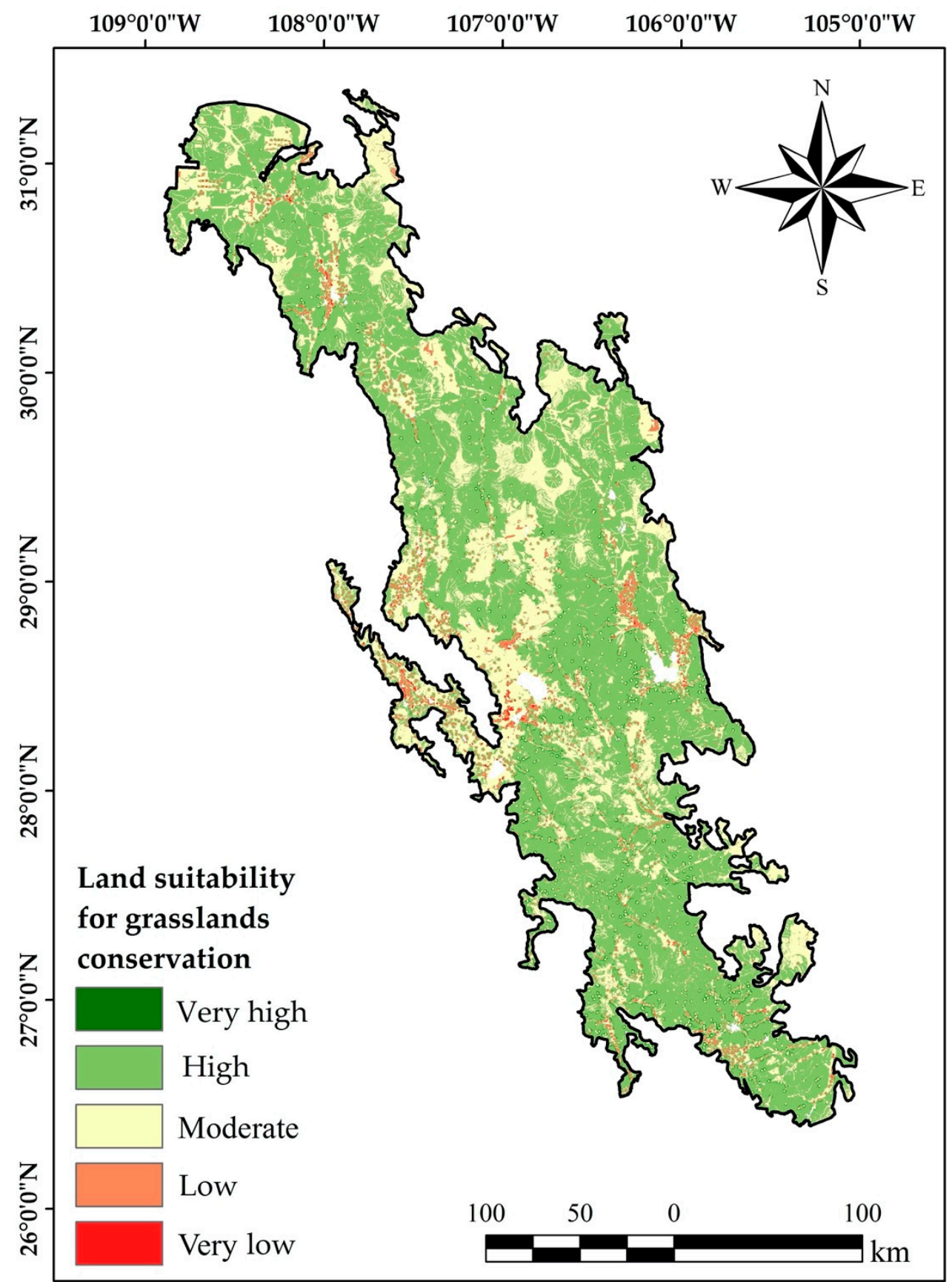

Figure 7. Spatial distribution of land suitability for grasslands conservation in the Central Valleys of the state of Chihuahua. Rural scenario.

\subsection{Land Suitability Configuration for Grasslands Conservation}

Landscape metrics provided information on the spatial configuration of the land-suitability classes for grasslands conservation. The metrics provide insights on fragmentation, connectivity, and heterogeneity measured at the landscape or class levels. At the landscape level, the number of patches and the density of patches were the highest for nonintensive agriculture (54,640 and 0.92), followed by the rural scenario $(46,210$ and 0.77$)$. The nonintensive agriculture and urban scenarios showed the highest edge density with values of 20.71 and 18.67 , respectively. The mean patch size showed the highest value (155.86) for the intensive agriculture scenario. The perimeter-area fractal dimension did not have large fluctuations among the scenarios, with the highest values corresponded to the urban and nonintensive agriculture scenarios. The intensive agriculture scenario presented the 
highest value of the Shannon's diversity index (1.0), followed by the nonintensive agriculture scenario with a value of 0.92 (Table 7).

Table 7. Landscape-level metrics used in the land-suitability configuration for grasslands conservation analysis for the Central Valleys of the state of Chihuahua, Mexico.

\begin{tabular}{ccccccc}
\hline Scenario & NumP & PD & ED & MPS & PAFRAC & SHDI \\
\hline Nonintensive Agriculture & 54,640 & 0.92 & 20.71 & 108.59 & 1.43 & 0.92 \\
Intensive Agriculture & 38,070 & 0.64 & 15.36 & 155.86 & 1.38 & 1.00 \\
Urban & 45,069 & 0.75 & 18.67 & 131.66 & 1.44 & 0.88 \\
Rural & 46,210 & 0.77 & 17.55 & 128.41 & 1.36 & 0.87 \\
\hline
\end{tabular}

NumP = Number of patches; PD = Patch density; ED = Edge density; MPS = Mean patch size; PAFRAC = Perimeter-area fractal dimension; SHDI = Shannon's diversity index.

The class level metrics for each scenario are summarized in Table 8. Class level fragmentation indices show differences within classes or land-suitability classes. An increase in the number of patches was registered for the moderate suitability class in the nonintensive agriculture and rural scenarios. Meanwhile, a smaller number of patches was shown for the Intensive agriculture and urban scenarios. The Euclidean nearest-neighbor distance reflected a decrease in class connectivity for all the scenarios, except for the nonintensive agriculture scenario.

Table 8. Class level metrics used in the land-suitability configuration for grasslands conservation analysis for the Central Valleys of the state of Chihuahua, Mexico.

\begin{tabular}{|c|c|c|c|c|c|c|c|c|c|c|c|c|}
\hline \multirow{2}{*}{ LSC } & \multicolumn{4}{|c|}{ PLAND } & \multicolumn{4}{|c|}{ NumP } & \multicolumn{4}{|c|}{ ED } \\
\hline & IntAgr & NIntAgr & Rural & Urban & IntAgr & NIntAgr & Rural & Urban & IntAgr & NIntAgr & Rural & Urban \\
\hline Very high & 2.0 & 2.1 & 1.8 & 10.0 & 5178 & 7783 & 6984 & 22,936 & 2.5 & 3.0 & 2.6 & 12.5 \\
\hline High & 57.2 & 59.5 & 64.1 & 73.3 & 11,058 & 11,584 & 9820 & 10,083 & 10.6 & 17.7 & 15.5 & 17.4 \\
\hline Moderate & 31.1 & 33.1 & 29.6 & 11.3 & 16,247 & 30,577 & 23,886 & 9853 & 12.9 & 17.6 & 13.9 & 5.5 \\
\hline Low & 9.4 & 5.2 & 4.3 & 5.2 & 4755 & 4346 & 4634 & 1580 & 4.4 & 3.0 & 2.8 & 1.6 \\
\hline Very low & 0.3 & 0.1 & 0.3 & 0.3 & 832 & 350 & 886 & 617 & 0.3 & 0.1 & 0.3 & 0.3 \\
\hline \multirow{2}{*}{ LSC } & \multicolumn{4}{|c|}{ MPS } & \multicolumn{4}{|c|}{ ENN_MN } & \multicolumn{4}{|c|}{ COHESION } \\
\hline & IntAgr & NIntAgr & Rural & Urban & IntAgr & NIntAgr & Rural & Urban & IntAgr & NIntAgr & Rural & Urban \\
\hline Very high & 22.5 & 15.8 & 15.7 & 25.7 & 359.3 & 331.5 & 378.5 & 263.9 & 88.4 & 86.4 & 84.4 & 95.4 \\
\hline High & 307.1 & 304.6 & 387.1 & 431.1 & 269.2 & 275.3 & 270.5 & 237.3 & 99.9 & 100.0 & 100.0 & 100.0 \\
\hline Moderate & 113.5 & 64.3 & 73.4 & 67.9 & 319.0 & 288.4 & 307.9 & 358.7 & 99.1 & 99.2 & 98.8 & 97.8 \\
\hline Low & 116.9 & 71.3 & 54.5 & 195.0 & 417.0 & 516.8 & 725.6 & 556.1 & 98.8 & 97.3 & 92.1 & 97.9 \\
\hline Very low & 24.7 & 17.7 & 18.6 & 30.9 & 1057.0 & 2074.8 & 1161.3 & 1231.8 & 86.5 & 84.5 & 83.7 & 87.6 \\
\hline
\end{tabular}

PLAND = Percentage of landscape; NumP = Number of patches; ED = Edge density; LSC = Land-suitability class; MPS = Mean patch size; ENN_MN = Euclidean nearest-neighbor distance; $C O H E S I O N=$ Patch cohesion index; IntAgr = Intensive agriculture; NIntAgr = Nonintensive agriculture.

\section{Discussions}

In several regions of the world, habitat fragmentation, caused by the increase in grazing areas, as well as by the increase in the agricultural surface area, are considered the main factors causing the loss of the grasslands structure and surface [62,63]. The demand for producing sufficient food from crops for public consumption is leading to the encroachment of agriculture over productive grasslands, where these converted grasslands are often premium-quality lands used by ranchers to graze their livestock during dry years to produce meat $[64,65]$. This represents a land use/land cover conflict, where, in many cases, grasslands get relegated to areas with low and very low suitability for the implementation of conservation activities. The Central Valleys of the state of Chihuahua do not escape from these pressures $[14,15]$. Therefore, zoning based on multiple criteria and subsequent conservation schemes are necessary [66]. This study contributes with knowledge about the zoning of grassland areas based on multiple criteria. Moreover, it provides insight on the spatial configuration of the LSGC in the Central Valleys of the state of Chihuahua, Mexico. 
The advantages of the MCE and WO techniques with a spatial approach have been reported previously [24]. These techniques were useful to identify the suitability, at different levels, of areas for conservation under four pressure scenarios. The manuscript also integrated a fragmentation analysis at the landscape and class levels, which provided a practical evaluation framework for prioritizing conservation decisions. The scenarios were constructed with seven criteria, which incorporated both natural attributes and proximity to anthropogenic disturbances. These criteria offered several advantages, such as the simplicity of obtaining or generating them at the chosen spatial scale, and the ease of modifying or extracting the desired data.

The results of this work, as well as previous studies [24,49], were useful for identifying different classes of land suitability. In the four scenarios generated, the areas with very low suitability for grasslands conservation are practically null. Likewise, the very high suitability class is also represented by small areas, except for the urban scenario. Regarding the total areas represented by each of the five land-suitability classes for grasslands conservation, the four scenarios showed similar values. However, the spatial distribution of such classes showed notorious differences.

The fragmentation analysis provided an understanding of the configuration of LSGC for different scenarios. Although the nonintensive agriculture scenario is dominated by the areas of high and moderate land-suitability classes, it shows the greatest number of patches, the greatest patch density, edge density, Shannon's diversity index and the smallest medium patch size (Table 5), which may be due to the influence of the small patches represented by plots of nonintensive agriculture, indicating that this scenario is fragmented. This was corroborated by the results from the metrics applied to the scenarios at five land-suitability classes (Table 6), where the number of patches, the percentage of the landscape, the edge density, and the cohesion were also higher for the moderate land suitability in the nonintensive agriculture scenario. For this scenario, the average patch size was the second smallest in the moderate class, followed by the rural scenario. In areas located nearby the study area, fragmentation has been assessed with similar metrics in previous studies, and the results show the presence of fragmentation $[67,68]$.

The connectivity indices indicate, in general, a low landscape connectivity for all the scenarios, especially for the low and very low suitability classes. In particular, for the nonintensive agriculture scenario, the patches of high suitability for grasslands conservation showed the greatest distance within them. This is due to the similar weights given to agriculture and rural communities (Table 2), which caused these two criteria to be drivers of alterations in this scenario. The opposite resulted for the urban scenario, where the area of high suitability proved to be the largest with the shortest distance between patches.

The heterogeneity for the four scenarios showed to be similar. The Shannon's diversity index for the rural scenario showed a value of 0.87 , being the least heterogeneous, while the scenario of intensive agriculture showed a value of 1.0, being the most heterogeneous. This is consistent with the findings reported by Sutti et al. [69] in a study on conservation areas for grassland birds.

This study integrated MCE and WO analysis with landscape fragmentation over four scenarios, which served to identify different classes of land suitability and their spatial configuration. This was possible by evaluating the fragmentation and its spatial representation in the four scenarios, providing information about the configuration of the landscape under different pressures. Previous studies have shown that drivers such as agriculture have altered the configuration of grassland ecosystems $[63,70,71]$. Such alteration has contributed to the decline of grassland bird species, which are distributed in the Central Valleys of Chihuahua [72]. Thus, our study highlights the importance of including agricultural as a driver of disturbance.

The results indicate the difference between the pressures given to the grassland ecosystems in each scenario, maintaining or decreasing the structure of the zones of LSGC and the patterns of the landscape. This is the first study of this kind, which integrates MCE-WO methodologies and fragmentation analysis, providing a starting point for grassland conservation planning. 
For the sake of practicality, repeatability, and simplicity of the model, the criteria were not exhaustive and only some criteria known for the definition of LSGC zones were included. However, additional criteria, such as information on actual management regimes, established conservation zones in the study area, socioeconomic criteria that may influence decisions on grassland habitat selection, could be incorporated. In this study, the proposed scenarios were generated by ranking, with the highest weight, the criterion, or criteria assumed to have the strongest influence on each scenario. It is worth mentioning that there exist additional methodologies for the assignment of weights [73]; however, we adhered to this particular one given its simplicity.

The choice of criteria with a knowledge-based approach, such as that of this study, is commonly applied in land-use planning studies [74,75]. Although this approach may become somewhat subjective compared to automated or data-driven approaches, it allows for more realistic results because it is based on local knowledge and from a review of a study previously developed in the study area [15].

Scenarios of LSGC, based on multicriteria evaluation, have a minimum of entry requirements and they can be easily modified [76]. Based on the availability of data from our interest, the modeling of land suitability for conservation can be applied for other ecosystems [77,78]. Several weights can be tested to explore different scenarios with the aim of developing policies that address specific problems [36].

If new rangeland zoning policies are put in place, it is easy to redesign the zoning exercise within a new context. To do this, various land demand scenarios can be constructed, modifying the area of the five conservation classes and repeating the whole analysis. This will make it possible to visualize and compare the effects of the different allocation policies under the different scenarios.

\section{Conclusions}

The integration of MCE-WO and fragmentation analysis is a valuable approach to estimate land suitability for grasslands conservation. The maps generated should be considered as a guiding tool for detecting lands with a high suitability for grasslands conservation. Managers and stakeholders can then make efforts in promoting conservation, as well as management practices on these lands, where they may have a greater chance of success.

In the Central Valleys of the state of Chihuahua, the areas with a high land suitability for grasslands conservation were distributed mainly in the central part of the study area. The seven criteria chosen served to assess the variability of the land suitability when a higher relative importance is assigned to different pressures, as it was represented by the several scenarios evaluated. Land suitability had a similar behavior for the intensive agriculture, urban, and rural scenarios.

Future research could include the central valleys, not just from Chihuahua. Grasslands do not respond based on geopolitical boundaries but on disturbances. Additional criteria, such as socioeconomic activities, actual zoning plans, and other landscape modifiers than the ones employed in this study, could be considered. This could lead to more comprehensive studies on the best locations to implement conservation management plans and activities.

Although the technique has been applied in this study for grasslands, it has the potential to be applicable for a multitude of other ecosystems or regions.

Author Contributions: Conceptualization, G.V.-Q. and F.V.-G.; Data curation, J.A.P.-A.; Formal analysis, A.P.-A.; Investigation, M.C.V.-A.; Software, G.V.-Q.; Supervision, A.P.-A.; Writing-original draft, G.V.-Q. and J.A.P.-A.; Writing-review \& editing, C.R.M.-N. and F.V.-G. All authors have read and agreed to the published version of the manuscript.

Funding: This research received no external funding.

Conflicts of Interest: The authors declare no conflict of interest. 


\section{References}

1. Xu, D.; Guo, X. Some insights on grassland health assessment based on remote sensing. Sensors 2015, 15, 3070-3089. [CrossRef] [PubMed]

2. Blanco, H.; Lal, R. Soil and water conservation. In Principles of Soil Conservation and Management, 1st ed.; Blanco, H., Lal, R., Eds.; Springer Science \& Business Media: New York, NY, USA, 2010; Volume 1, pp. 1-16.

3. Fan, J.; Zhong, H.; Harris, W.; Yu, G.; Wang, S.; Hu, Z.; Yue, Y. Carbon storage in the grasslands of China based on field measurements of above-and below-ground biomass. Clim. Chang. 2008, 86, 375-396. [CrossRef]

4. Zuazo, V.H.D.; Pleguezuelo, C.R.R. Soil-erosion and runoff prevention by plant covers: A review. In Sustainable Agriculture, 1st ed.; Lichtfouse, E., Navarrete, M., Debaeke, P., Véronique, S., Alberola, C., Eds.; Springer: Dordrecht, The Netherlands; Heidelberg, Germany; London, UK; New York, NY, USA, 2009; pp. 785-811.

5. Jurado, G.P.; Saucedo, T.R.A.; Morales, N.C.R.; Martínez, S.M. Almacén y Captura de Carbono en Pastizales y Matorrales de Chihuahua; INIFAP: Chihuahua, Mexico, 2013.

6. Lamarque, P.; Tappeiner, U.; Turner, C.; Steinbacher, M.; Bardgett, R.D.; Szukics, U.; Scherme, M.; Lavorel, S. Stakeholder perceptions of grassland ecosystem services in relation to knowledge on soil fertility and biodiversity. Reg. Environ. Chang. 2011, 11,791-804. [CrossRef]

7. Cheng, X.; An, S.; Chen, J.; Li, B.; Liu, Y.; Liu, S. Spatial relationships among species, above-ground biomass, $\mathrm{N}$, and $\mathrm{P}$ in degraded grasslands in Ordos Plateau, northwestern China. J. Arid Environ. 2007, 68, 652-667. [CrossRef]

8. Gang, C.; Zhou, W.; Chen, Y.; Wang, Z.; Sun, Z.; Li, J.; Qi, J.; Odeh, I. Quantitative assessment of the contributions of climate change and human activities on global grassland degradation. Environ. Earth Sci. 2014, 72, 4273-4282. [CrossRef]

9. Facelli, J.M.; Temby, A.M. Multiple effects of shrubs on annual plant communities in arid lands of South Austrlia. Austral Ecol. 2002, 27, 422-432. [CrossRef]

10. He, C.; Zhang, Q.; Li, Y.; Li, X.; Shi, P. Zoning grassland protection area using remote sensing and cellular automata modeling-A case study in Xilingol steppe grassland in northern China. J. Arid Environ. 2005, 63, 814-826. [CrossRef]

11. Gellesch, E.; Khan, M.A.A.; Jentsch, A.; Beierkuhnlein, C. Grassland experiments under climatic extremes: Reproductive fitness versus biomass. Environ. Exp. Bot. 2017, 144, 68-75. [CrossRef]

12. Concilio, A.L.; Prevéy, J.S.; Omasta, P.; O'Connor, J.; Nippert, J.B.; Seastedt, T.R. Response of a mixed grass prairie to an extreme precipitation event. Ecosphere 2015, 6, 1-12. [CrossRef]

13. Mas, J.F.; Velázquez, A.; Díaz-Gallegos, J.R.; Mayorga-Saucedo, R.; Alcántara, C.; Bocco, G.; Castro, R.; Fernández, T.; Pérez-Vega, A. Assessing land use/cover changes: A nationwide multidate spatial database for Mexico. Int. J. Appl. Earth Obs. Geoinf. 2004, 5, 249-261. [CrossRef]

14. Estrada-Castillón, E.; Scott-Morales, L.; Villarreal-Quintanilla, J.A.; Jurado-Ybarra, E.; Cotera-Correa, M.; Cantú-Ayala, C.; García-Pérez, J. Clasificación de los pastizales halófilos del noreste de México asociados con perrito de las praderas (Cynomys mexicanus): Diversidad y endemismo de especies. Rev. Mex. Biodivers. 2010, 81, 401-416. [CrossRef]

15. Manjarrez-Dominguez, C.; Pinedo-Alvarez, A.; Pinedo-Alvarez, C.; Villarreal-Guerrero, F.; Cortes-Palacios, L. Vegetation landscape analysis due to land use changes on arid lands. Pol. J. Ecol. 2015, 63, 167-175. [CrossRef]

16. Instituto Nacional de Estadistica, Geografía en Informatica (INEGI). Sintesis de información geográfica del Estado de Chihuahua, 1st ed.; Instituto Nacional de Estadística, Geografía e Informática: Aguascalientes, Mexico, 2003; p. 113.

17. Margules, C.R.; Pressey, R.L. Systematic conservation planning. Nature 2000, 405, 243-253. [CrossRef]

18. Meffe, G.K.; Nielsen, L.A.; Knight, R.L.; Schenborn, D.A. Ecosystem Management: Adaptive, Community-Based Conservation; Island Press: Washington, DC, USA, 2002; pp. 169-184.

19. Knight, A.T.; Cowling, R.M. Embracing opportunism in the selection of priority conservation areas. Conserv. Biol. 2007, 21, 1124-1126. [CrossRef]

20. Walke, N.; Reddy, G.O.; Maji, A.K.; Thayalan, S. GIS-based multicriteria overlay analysis in soil-suitability evaluation for cotton (Gossypium spp.): A case study in the black soil region of central India. Comput. Geosci. 2012, 41, 108-118. [CrossRef]

21. Zolekar, R.B.; Bhagat, V.S. Multi-criteria land suitability analysis for agriculture in hilly zone: Remote sensing and GIS approach. Comput. Electron. Agric. 2015, 118, 300-321. [CrossRef] 
22. Aldababseh, A.; Temimi, M.; Maghelal, P.; Branch, O.; Wulfmeyer, V. Multi-criteria evaluation of irrigated agriculture suitability to achieve food security in an arid environment. Sustainability 2018, 10, 803. [CrossRef]

23. Massam, B.H. Multi-criteria decision making techniques in planning. Prog. Plan. 1988, 30, 1-84. [CrossRef]

24. Geneletti, D.; van Duren, I. Protected area zoning for conservation and use: A combination of spatial multicriteria and multiobjective evaluation. Landsc. Urban Plan. 2008, 85, 97-110. [CrossRef]

25. Pereira, J.M.C.; Duckstein, L. A multiple criteria decision-making approach to GIS based land suitability evaluation. Int. J. Geogr. Inf. Sci. 1993, 7, 407-424. [CrossRef]

26. Malczewski, J. GIS-based land-use suitability analysis: A critical overview. Prog. Plan. 2004, 62, 3-65. [CrossRef]

27. Eastman, R. Multi-criteria evaluation and GIS. Chapter 35. In Geographical Information Systems; Longley, P.A., Goodchild, M.F., Maguire, D.J., Rhind, D.W., Eds.; Wiley: New York, NY, USA, 1999; pp. 493-502.

28. Cengiz, T.; Akbulak, C. Application of analytical hierarchy process and geographic information systems in land-use suitability evaluation: A case study of Dümrek village (Çanakkale, Turkey). Int. J. Sustain. Dev. World Ecol. 2009, 16, 286-294. [CrossRef]

29. Mendas, A.; Delali, A. Integration of MultiCriteria Decision Analysis in GIS to develop land suitability for agriculture: Application to durum wheat cultivation in the region of Mleta in Algeria. Comput. Electron. Agric. 2012, 83, 117-126. [CrossRef]

30. Huth, A.; Drechsler, M.; Köhler, P. Using multicriteria decision analysis and a forest growth model to assess impacts of tree harvesting in Dipterocarp lowland rain forests. For. Ecol. Manag. 2005, 207, $215-232$. [CrossRef]

31. Pourghasemi, H.R.; Pradhan, B.; Gokceoglu, C. Application of fuzzy logic and analytical hierarchy process (AHP) to landslide susceptibility mapping at Haraz watershed, Iran. Nat. Hazards 2012, 63, 965-996. [CrossRef]

32. Torrieri, F.; Batà, A. Spatial multi-criteria decision support system and strategic environmental assessment: A case study. Buildings 2017, 7, 96. [CrossRef]

33. Hailegebriel, S. Irrigation Potential Evaluation and Crop Suitability Analysis Using GIS and Remote Sensing Technique in Beles Sub Basin, Beneshangul Gumez Region. Master's Thesis, Addis Ababa Universty, Addis Ababa, Ethiopia, 2007.

34. Zelalem, A. Land Use/Land Cover Dynamics and Vegetation Vulnerability Analysis: A Case Study of Arsi Negele Wereda. Master's Thesis, Addis Ababa Universty, Addis Ababa, Ethiopia, 2007.

35. Girard, L.F.; Cerreta, M.; De Toro, P. Integrated spatial assessment: A multidimensional approach for sustainable planning. In Proceedings of the MTISD 2008-Methods, Models and Information Technologies for Decision Support System, Lecce, Italy, 18-20 September 2008; pp. 277-280.

36. Mayfield, C.J. Automating the Classification of Thematic Rasters for Weighted Overlay Analysis in GeoPlanner for ArcGIS. Master's Thesis, University of Redlands, Redlands, CA, USA, 2016.

37. Camacho Olmedo, M.T.C.; Paegelow, M.; Mas, J.F.; Escobar, F. Geomatic Approaches for Modeling Land Change Scenarios; Springer: Cham, Switzerland, 2018; pp. 27-30.

38. Rodewald, A.D. The importance of land uses within the landscape matrix. Wildl. Soc. Bull. 2003, 31, 586-592.

39. Comisión Nacional para el Conocimiento y Uso de la Biodiversidad (CONABIO). La Biodiversidad en Chihuahua: Estudio de Estado; Comisión Nacional para el Conocimiento y Uso de la Biodiversidad: Distrito Federal, Mexico, 2014.

40. International Union for Conservation of Nature (IUCN). Nature-Based Solutions. 2016. Available online: http://www.iucn.org/regions/europe/our-work/nature-based-solutions (accessed on 16 December 2019).

41. Guerrero, P.; Haase, D.; Albert, C. Locating spatial opportunities for nature-based solutions: A river landscape application. Water 2018, 10, 1869. [CrossRef]

42. Stürck, J.; Schulp, C.J.; Verburg, P.H. Spatio-temporal dynamics of regulating ecosystem services in Europe-The role of past and future land use change. Appl. Geogr. 2015, 63, 121-135. [CrossRef]

43. Cohen-Shacham, E.; Walters, G.; Janzen, C.; Maginnis, S. Nature-Based Solutions to Address Global Societal Challenges; IUCN: Gland, Switzerland, 2016; pp. 2-10.

44. Chen, F.; Li, L.; Niu, J.; Lin, A.; Chen, S.; Hao, L. Evaluating Ecosystem Services Supply and Demand Dynamics and Ecological Zoning Management in Wuhan, China. Int. J. Environ. Res. Public Heath 2019, 16, 2332. [CrossRef] 
45. Comisión Nacional para el Conocimiento y Uso de la Biodiversidad (CONABIO). Sierra del Nido-Pastizal de Flores Magón. Available online: http://www.conabio.gob.mx/conocimiento/regionalizacion/doctos/rtp_047. pdf (accessed on 20 January 2019).

46. García, E. Climas (Clasificación de Köeppen, Modificado por García) Escala 1:1000,000; CONABIO: Distrito Federal, Mexico, 1998.

47. Samson, F.B.; Knopf, F.L.; Ostlie, W.R. Great Plains ecosystems: Past, present, and future. Wildl. Soc. Bull. 2004, 32, 6-15. [CrossRef]

48. International Union for Conservation of Nature (IUCN). Available online: http://www.iucnredlist.org/details/ 18868/0 (accessed on 20 January 2019).

49. Davies, A.L.; Bryce, R.; Redpath, S.M. Use of multicriteria decision analysis to address conservation conflicts. Conserv. Biol. 2013, 27, 936-944. [CrossRef] [PubMed]

50. Instituto Nacional de Geografía e Informática. Uso del Suelo y Vegetación. Available online: https: //www.inegi.org.mx/temas/usosuelo/default.html\#Descargas (accessed on 20 February 2018).

51. Instituto Nacional de Geografía e Informática. Marco Geoestadistico. Available online: https://www.inegi. org.mx/temas/mg/default.html\#Descargas (accessed on 20 February 2018).

52. Instituto Nacional de Geografía e Informática. Simulador de Flujos de Agua de Cuencas Hidrográficas. Available online: http://antares.inegi.org.mx/analisis/red_hidro/siatl/\# (accessed on 20 February 2018).

53. Instituto Nacional de Geografía e Informática. Continuo de elevaciones mexicano (CEM). Available online: https://www.inegi.org.mx/app/geo2/elevacionesmex/ (accessed on 20 February 2018).

54. Instituto Nacional de Geografía e Informática. Edafología. Available online: https://www.inegi.org.mx/ temas/edafologia/default.html\#Descargas (accessed on 20 February 2018).

55. Food and Agriculture Organization of the United Nations. A Framework for Land Evaluation; FAO: Rome, Italy, 1977.

56. Gorsevski, P.V.; Donevska, K.R.; Mitrovski, C.D.; Frizado, J.P. Integrating multi-criteria evaluation techniques with geographic information systems for landfill site selection: A case study using ordered weighted average. Waste Manag. 2012, 32, 287-296. [CrossRef] [PubMed]

57. McGarigal, K.; Marks, B. FRAGSTATS: Spatial Pattern Analysis Program for Quantifying Landscape Structure. USDA Forest Service General Technical Report PNW-GTR-351. 1995. Available online: https: //www.fs.fed.us/pnw/pubs/pnw_gtr351.pdf (accessed on 13 February 2019).

58. Mas, J.F.; Pérez-Vega, A.; Clarke, K.C. Assessing simulated land use/cover maps using similarity and fragmentation indices. Ecol. Complex 2012, 11, 38-45. [CrossRef]

59. Sohares-Filho, B.; Silvestrini, R.; Nepstad, D.; Brando, P.; Rodrigues, H.; Alencar, A.; Coe, M.; Locks, C.; Lima, L.; Hissa, L.; et al. Forest fragmentation, climate change and understory fire regimes on the Amazonian landscapes of the Xingu headwaters. Lands. Ecol. 2012, 27, 585-598. [CrossRef]

60. McGarigal, K.; Cushman, S.A.; Neel, M.C.; Ene, E. FRAGSTATS: Spatial Pattern Analysis Program for Categorical Maps. 2002. Available online: www.umass.edu/landeco/research/fragstats/fragstats.html (accessed on 20 March 2019).

61. De León Mata, G.D.; Pinedo Álvarez, A.; Martínez Guerrero, J.H. Aplicación de sensores remotos en el análisis de la fragmentación del paisaje en cuchillas de la zarca, México. Investigaciones Geográficas 2014, 84, 42-53. [CrossRef]

62. Otuoma, J.; Kinyamario, J.; Ekaya, W.; Kshatriya, M.; Nyabenge, M. Effects of human-livestock-wildlife interactions on habitat in an eastern Kenya rangeland. Afr. J. Ecol. 2009, 47, 567-573. [CrossRef]

63. Reino, L.; Beja, P.; Araujo, M.B.; Dray, S.; Segurado, P. Does local habitat fragmentation affect large-scale distributions? The case of a specialist grassland bird. Divers. Distrib. 2013, 19, 423-432. [CrossRef]

64. Dodd, J. Desertification and degradation of Africa's rangelands. Rangelands 1994, 16, 180-183.

65. Rashford, B.S.; Walker, J.A.; Bastian, C.T. Economics of grassland conversion to cropland in the Prairie Pothole Region. Conserv. Biol. 2011, 25, 276-284. [CrossRef]

66. Janišová, M.; Bartha, S.; Kiehl, K.; Dengler, J. Advances in the conservation of dry grasslands: Introduction to contributions from the seventh European Dry Grassland Meeting. Plant Biosyst. Int. J. Deal. All Asp. Plant Biol. 2011, 145, 507-513. [CrossRef]

67. Martínez-Estévez, L.; Balvanera, P.; Pacheco, J.; Ceballos, G. Prairie dog decline reduces the supply of ecosystem services and leads to desertification of semiarid grasslands. PLoS ONE 2013, 8, e75229. [CrossRef] [PubMed] 
68. Pool, D.B.; Panjabi, A.O.; Macias-Duarte, A.; Solhjem, D.M. Rapid expansion of croplands in Chihuahua, Mexico threatens declining North American grassland bird species. Biol. Conserv. 2014, 170, $274-281$. [CrossRef]

69. Sutti, F.; Strong, A.; Perlut, N. A multicriteria decision analysis for identifying priority conservation areas 472 for grassland birds. Northeast Nat. 2017, 24, 99-119. [CrossRef]

70. Hoekstra, J.M.; Boucher, T.M.; Ricketts, T.H.; Roberts, C. Confronting a biome crisis: Global disparities of habitat loss and protection. Ecol. Lett. 2005, 8, 23-29. [CrossRef]

71. Zhou, X.; Helmers, M.J.; Asbjornsen, H.; Kolka, R.M.; Tomer, M.D. Perennial filter strips reduce nitrate levels in soil and shallow groundwater after grassland-to-cropland conversion. J. Environ. Qual. 2010, 39, 2006-2015. [CrossRef]

72. Macias-Duarte, A.; Panjabi, A.O.; Pool, D.; Youngberg, E.; Levandoski, G. Wintering Grassland Bird Density in Chihuahuan Desert Grassland Priority Conservation Areas, 2007-2011. Rocky Mountain Bird Observatory, Brighton, CO, RMBO Technical, Report I-NEOTROP-MXPLAT-10-2. Available online: https://birdconservancy.org/wp-content/uploads/2014/06/2011_Chihuahuan_Desert_Grassland_Bird_ report_with_appendixAB.pdf (accessed on 18 February 2019).

73. Malczewski, J. GIS and Multicriteria Decision Analysis; John Wiley \& Sons: New York, NY, USA, 1999; pp. 177-192.

74. Krueger, T.; Page, T.; Hubacek, K.; Smith, L.; Hiscock, K. The role of expert opinion in environmental modelling. Environ. Model. Softw. 2012, 36, 4-18. [CrossRef]

75. Prieto-Amparán, J.A.; Villarreal-Guerrero, F.; Martínez-Salvador, M.; Manjarrez-Domínguez, C.; Vázquez-Quintero, G.; Pinedo-Alvarez, A. Spatial near future modeling of land use and land cover changes in the temperate forests of Mexico. PeerJ 2019, 7, e6617. [CrossRef]

76. Bottero, M.; Comino, E.; Duriavig, M.; Ferretti, V.; Pomarico, S. The application of a Multicriteria Spatial Decision Support System (MCSDSS) for the assessment of biodiversity conservation in the province of Varese (Italy). Land Use Policy 2013, 30, 730-738. [CrossRef]

77. Garmendia, E.; Gamboa, G. Weighting social preferences in participatory multi-criteria evaluations: A case study on sustainable natural resource management. Ecol. Econ. 2012, 84, 110-120. [CrossRef]

78. Nguyen, T.T.; Verdoodt, A.; Van Y, T.; Delbecque, N.; Tran, T.C.; Van Ranst, E. Design of a GIS and multi-criteria based land evaluation procedure for sustainable land-use planning at the regional level. Agric. Ecosyst. Environ. 2015, 200, 1-11. [CrossRef] 